\title{
Patterns of Interracial and Interethnic Marriages among Foreign-Born Asians in the United States
}

\author{
Philip Yang ${ }^{1, *}$ and Maggie Bohm-Jordan ${ }^{2}$ (1) \\ 1 Department of Sociology and Social Work, Texas Woman's University, Denton, TX 76204, USA \\ 2 Department of Sociology and Social Work, University of Wisconsin-Stevens-Point, Stevens Point, WI 54481, \\ USA; mbohmjor@uwsp.edu \\ * Correspondence: pyang@twu.edu; Tel.: +1-940-898-2054
}

Received: 6 August 2018; Accepted: 12 September 2018; Published: 16 September 2018

check for updates

\begin{abstract}
This study examines the patterns of interracial marriage and interethnic marriage among foreign-born Asians in the United States, using pooled data from the 2008-2012 American Community Surveys. Results show that the most dominant pattern of marriage among foreign-born Asians was still intra-ethnic marriage and that interracial marriage, especially with whites, rather than interethnic marriage among Asians, remained the dominant pattern of intermarriages. Out of all foreign-born Asian marriages, inter-Asian marriages stayed at only about 3\%. Among all foreign-born Asian groups, Japanese were most likely to marry interracially and interethnically, while Asian Indians had the lowest rates of interracial marriage and interethnic marriage. Foreign-born Asian women were more likely to interracially marry, especially with whites, than foreign-born Asian men, but they were not much different from foreign-born Asian men in terms of their interethnic marriage rate. The findings have significant implications for intermarriage research, assimilation, and Asian American panethnicity.
\end{abstract}

Keywords: intermarriage; interracial marriage; interethnic marriage; foreign-born Asians; assimilation; Asian American panethnicity

\section{Introduction}

Intermarriage is part of assimilation [1] and a barometer of social integration and intergroup social distance. Intermarriage can be interracial (e.g., between Asian and white) or interethnic (e.g., between Chinese and Korean). For Asian Americans, interracial marriage and interethnic marriage have differential implications. While interracial marriage between Asians and whites signifies assimilation to the dominant culture and society, interethnic marriage among Asian ethnic groups indicates integration into Asian American panethnicity [2], a concept most fully developed by Yen Espiritu [3] and Lopez and Espiritu [4]. Because of the differential implications of interracial marriage and interethnic marriage, it is important to understand the patterns of interracial marriage and interethnic marriage among Asian Americans, the large majority of whom are foreign-born.

There are significant differences between native-born Asians and foreign-born Asians in intermarriages [2,5-7]. Nevertheless, the bulk of existing research on Asian intermarriages lumps Asians together without considering nativity, or focuses on native-born Asians, and seldom distinguishes between interracial marriage and interethnic marriage when examining foreign-born Asians [8-15]. There is only limited research on the patterns of intermarriages among foreign-born Asians $[7,16]$. An exception is the study conducted by Qian, Blair, and Ruf [2], which did consider intermarriage by nativity. However, they included only foreign-born Asian couples aged 20-34 for the purpose of their study using the 1990 Public Use Microdata Sample (PUMS) data. Although restricting analysis to couples aged 20-34 may reduce sample selection bias, it cannot determine the 
marriage patterns of all foreign-born Asians. It is important to study the intermarriages of foreign-born Asians because the majority of Asian Americans are foreign-born and the intermarriage patterns of all Asian Americans may not be the same as the patterns of foreign-born Asians or native-born Asians. It is inadequate to only study the intermarriage patterns of native-born Asians, despite their high likelihood of getting married in the U.S., because they are only part of the whole group of Asian Americans. Bohra-Mishra and Massey [16] also cast doubt on the unsubstantiated assumption that most immigrants in the U.S., Asian immigrants included, got married before immigration, and, in fact, data from the U.S. Citizenship and Immigration Service [17] indicate that only around half of all immigrants were currently married at the time of arrival.

Furthermore, past research on Asian intermarriages tends to focus mainly on Asian-white interracial marriages [9,18-20]. Nonetheless, the Asian-white intermarriage rate declined from 1980 to 2000 [12,21-23]. On the other hand, using the PUMS data from the 1980 and 1990 censuses, Lee and Fernandez [12] revealed that interethnic marriage rates among Asians increased from 1980 to 1990 at the national level. Interethnic marriage rates even surpassed interracial marriage rates between Asians and non-Asians in California in 1990 [24]. It is likely that interethnic marriage rates among Asians have continued to increase since 1990. Some claims [24] notwithstanding, we have not seen evidence indicating that at the national level interethnic marriages have become the dominant type of intermarriages among foreign-born Asians, native-born Asians, or Asian Americans en masse, much less ethnic and gender differences in intermarriage patterns in that regard.

To fill the gaps in the literature, this study examines the patterns of intermarriages among foreign-born Asians by differentiating between interracial marriage and interethnic marriage. We follow the U.S. Census Bureau's definition of Asian-“a person having origins in any of the original peoples of the Far East, Southeast Asia, or the Indian subcontinent (e.g., Cambodia, China, Indian, Japan, Korea, Malaysia, Pakistan, the Philippine Islands, Thailand, and Vietnam)". Three research questions drive this study: (1) What is the dominant pattern of intermarriage among foreign-born Asians? Put differently, are foreign-born Asians more likely to engage in interethnic marriage than interracial marriage or the opposite? (2) How do different ethnic groups of foreign-born Asians differ in interracial and interethnic marriages? (3) How do intermarriage patterns differ by gender among foreign-born Asians? The balance of this paper reviews the literature pertinent to the research questions, suggests possible intermarriage patterns to be expected, describes the data and methods, presents our findings, and discusses the implications of the findings.

\section{Literature Review}

In this section, we briefly assess the literature germane to our research questions on the dominant pattern of intermarriages, including interracial and interethnic marriages among Asian immigrants and Asian Americans and variations in intermarriage patterns among different Asian ethnic groups and across the gender line. In the process, we also develop our expectations about what patterns may come out of the data.

\subsection{Dominant Patterns of Asian Intermarriages}

The dominant pattern of intermarriage among Asian immigrants and Asian Americans is not static and should be examined from a historical perspective. Changes in the dominant pattern of Asian intermarriages may be divided into the following three periods:

First, from the beginning of significant Asian immigration in 1848 until the end of World War II in 1945, "a dearth of intermarriages" appeared to be a proper characterization of intermarriage patterns among Asians in the U.S. Intramarriage, which is defined as a marriage within the same race or ethnic group, dominated the pattern of marriages among Asians in the U.S. $[5,25,26]$. The main reason for this dominant marriage pattern was the anti-miscegenation laws that prevented Asians from marrying whites. In addition, the Gentlemen's Agreement of 1907-1908 permitted Japanese laborers already in 
the U.S. to send for their spouses and children, and therefore reduced their need to marry out. During this era, interracial marriages accounted for the lowest proportion of marriages among Asians [27-30].

Second, from the end of World War II to the 1970s (1945-1979) a pattern of "growing interracial marriages" emerged between Asians and non-Asians. Although intramarriage remained the dominant marriage pattern, interracial marriages increased sharply and became the dominant pattern of intermarriages among Asian Americans during this period. The principle cause of such increases in interracial marriages right after World War II was the marriages between U.S. soldiers stationed in Asian countries and Asian "war brides." During this period, Asian immigrants gradually gained eligibility for U.S. citizenship, and U.S. servicemen were allowed to marry overseas and bring their wives, regardless of racial backgrounds, to the U.S. because of the War Brides Act of 1945, the Alien Fiancées and Fiancés Act of 1946, the Chinese Alien Wives of American Citizens Act of 1946, and the Immigration and Nationality Act of 1952 [7]. A large number of such interracial marriages were between American soldiers and women in countries with a large non-white population [31]. The U.S. military presence in Japan, Korea, and the Philippines especially explained the high intermarriage rates among foreign-born Asian women [32].

The post-World War II period also witnessed the gradual repeal of the anti-miscegenation laws in more and more states, especially states where Asian Americans were concentrated. Finally, in the Loving v. Virginia ruling in 1967, the U.S. Supreme Court found anti-miscegenation statutes unconstitutional and paved the way for growing acceptance of interracial marriages. As a result, more Asians married whites than ever before [26]. Nevertheless, interethnic marriages between Asians were still uncommon among Asian groups, although they did exist, especially between Japanese and Chinese [26]. Despite some increases in interethnic marriages among Asians in the 1970s [3], interracial marriages, especially with whites, remained the dominant pattern of intermarriages.

Finally, since 1980, nationally there have been significant "growing interethnic marriages" among Asians [11-13], though interethnic marriages have not yet surpassed interracial marriages. Lee and Yamanaka [13] demonstrated significant rates of interethnic marriages among all Asians (10.7\%) and the six largest Asian groups in 1980. Lee and Fernandez [12] found even greater increases in the rates of interethnic marriages among all Asians (21.2\%) and the six largest Asian groups across the board in 1990. In particular, in California where Asians were highly concentrated, the rate of interethnic marriages among Asians surpassed the rate of interracial marriages between Asians and non-Asians in 1990 [24]. Phenomenal growth in the Asian population, a dramatic increase in pan-Asian consciousness and identity, a strong development of pan-Asian organizations and social and personal networks, increasing similarity in socioeconomic status among Asian groups, and acculturation of Asian Americans may have contributed to the substantial growth in Asian interethnic marriages [3,12,24]. The pattern of growing interethnic marriage among Asians appears to continue in the twenty-first century because of a substantial increase in the Asian population and a movement towards Asian panethnicity [23]. An important limitation to keep in mind is that the bulk of the evidence combines Asians as a whole without differentiating the foreign-born from the native-born. What is lacking is evidence that documents the current dominant pattern of intermarriage among Asian Americans, especially Asian immigrants, at the national level.

Based on the ongoing shifts in Asian intermarriages reviewed above, we expect the rate of interethnic marriages among foreign-born Asians to rise continuously at the national level, but we suspect that the rate of interethnic marriages could overtake the rate of interracial marriages. We believe that the continuing increase in the Asian population, fanned by Asian immigration coupled with growing pan-Asian awareness and identity, constitutes the basis for the increasing interethnic marriage rate among foreign-born Asians. As the Asian population continued to increase substantially in the twenty-first century, with 15 million based on single-race to 17 million based on single-race or in combination of two or more races in 2010, the opportunity for Asians to interact and marry among themselves also increased significantly. The wide acceptance of Asian American identity and the Asian American awareness reinforced by Asian American studies courses on college campuses reduce social 
distance between different Asian ethnic groups and increase the chances of interethnic marriages among Asians. Asian parents tend to prefer their children to marry within their own ethnic group or at least within Asian groups rather than to interracially marry [33]. The evidence of interethnic marriage surpassing interracial marriage found in California in 1990 by Shinagawa and Pang [24] signaled such a shift at the national level. However, we do not think that, at the national level, based on the rates of interethnic marriages in 1980 and 1990, the increase in a couple of decades could surpass the rates of interracial marriages, which were in the range of $20 \%-30 \%$.

\subsection{Patterns of Asian Intermarriages by Ethnicity}

Available evidence for the period of 1980-2000 from the 5\% PUMS data from the 1980, 1990, and 2000 censuses suggested that there were significant differences in intermarriages among foreign-born Asian groups [7,11-13]. Foreign-born Japanese had the highest rates of intermarriage, while foreign-born Asian Indians had the lowest intermarriage rates; the rates of foreign-born Chinese were very close to those of foreign-born Asian Indians; and the rates of foreign-born Filipinos, foreign-born Koreans, and foreign-born Vietnamese fell somewhere in between.

Intermarriage rates also vary over time across foreign-born Asian groups. The data based on the $5 \%$ PUMS data from the 1980, 1990, and 2000 censuses [7,11,12] indicated that the intermarriage rates of foreign-born Filipinos, foreign-born Asian Indians, and foreign-born Chinese had remained almost constant, but the rates of foreign-born Koreans and foreign-born Vietnamese had declined significantly. In particular, the intermarriage rates of foreign-born Koreans steadily decreased from 30\% in 1980 to $21 \%$ in 1990 and to $19 \%$ in 2000 . The dramatic declines among foreign-born Koreans may be related to the "internationally in-married"-Korean immigrants in the U.S. return to Korea to marry Koreans and then bring the newlywed spouses to the U.S. [34,35]. The intermarriage rates of foreign-born Japanese had fluctuated [7].

A major limitation of the literature is that existing studies do not distinguish between interracial marriage and interethnic marriage but lump both into intermarriage. Another limitation is that the information on intermarriage rates is limited to the six largest foreign-born Asian groups, but unavailable for newer and smaller Asian immigrant groups (e.g., Pakistani, Sri Lankan). Finally, the data cover the period up to 2000 and need an update.

We anticipate significant differences in interracial or interethnic marriages among different Asian immigrant groups because of differences across foreign-born Asian groups in culture and close connections with the U.S., and the evidence in the literature [11,22].

\subsection{Patterns of Asian Intermarriages by Gender}

Synthesizing the 5\% PUMS data from the 1980, 1990, and 2000 censuses provided by Lee and Boyd [11] and Lee and Fernandez [12], Yang [7] showed that for foreign-born Asians as a whole, women were more likely to intermarry than men, but the gender difference in the intermarriage rate narrowed from 1980 to 2000. He also revealed that among the foreign-born, Japanese, Korean, and Filipino women were much more likely to intermarry than their respective male counterparts, Chinese women were only somewhat more likely to intermarry than Chinese men, and Vietnamese women were much more likely to intermarry in 1980 but only somewhat more likely to do so in 1990; in contrast, Asian Indian women were less likely to intermarry than their male counterparts.

Some studies provide information on interracial marriage and interethnic marriage but do not break down by nativity. For example, using data from the 1980 to 2000 censuses Okamoto [15] found higher rates of intermarriages among Asian women than among Asian men but a narrowing gender gap in intermarriages. In 1980, 29.3\% of Asian women intermarried, including 91\% interracial marriages among all the intermarriages, but only $14.7 \%$ of Asian men intermarried, including $78.8 \%$ interracial marriages. In 1990, 24.5\% of Asian women intermarried, including $89.9 \%$ interracial marriages, but nearly $12.8 \%$ of Asian men did so, including $77.5 \%$ interracial marriages. In 2000, $24.7 \%$ of Asian 
women intermarried, including $89.1 \%$ interracial marriages, while for men there was only a minimal change from 1990 with $13.4 \%$ intermarriages and $76.6 \%$ interracial marriages.

The majority of Asian interracial marriages for both genders are with whites, yet Asian women have a higher rate of interracial marriages with whites than Asian men. Asian women are somewhat more likely to interracially marry with blacks than their male counterparts, and Asian men are more likely to marry a Hispanic spouse than Asian women [21]. Yet, Chinese men are less likely to out-marry compared to Japanese and Filipino men, although Japanese men are more likely than Filipino men to out-marry [36]. Specifically, there was a huge increase for native-born Asians to marry foreign-born Asians from $7.5 \%$ in 1980 to $20 \%$ in 2008 for men and from $4.3 \%$ in 1980 to $21.4 \%$ in 2008 for women [37].

The limitations for the patterns of foreign-born Asian intermarriages by ethnicity also apply to the patterns of foreign-born Asian intermarriages by gender. Again, a main limitation is that the data do not break down by interracial marriage and interethnic marriage. In addition, data are not available beyond the six largest foreign-born Asian groups and need an update beyond 2000.

We expect that foreign-born Asian women were more likely to intermarry than foreign-born Asian men, but the gender gap varied across different foreign-born Asian immigrant groups. Available evidence has shown that foreign-born Asian women were more likely to intermarry than foreign-born Asian men, with the exception that foreign-born Asian Indian men were more likely to intermarry than their female counterparts [11,12], but different Asian immigrant groups vary in gender difference in intermarriage rate [7].

\section{Data and Methods}

\subsection{Data}

To answer our research questions, this study utilizes the pooled data from the Integrated Public Use Microdata Series (IPUMS-USA) 2008-2012 American Community Surveys (ACS) collected by the U.S. Census Bureau and integrated by the Minnesota Population Center at the University of Minnesota [38]. We restricted our analysis to foreign-born Asian householders who were married with spouse present [39]. The restricted sample size was 121,042. We pooled the five years of ACS data to ensure that the sample sizes of sub-Asian immigrant groups are sufficiently large for reliable statistical analysis. ACS 2008-2012 are nationally representative samples of the U.S. population, so our findings can be generalized to the U.S. population. With large sample sizes, ACS 2008-2012 provide the latest best available data to study the patterns of intermarriages among married foreign-born Asians. A limitation is that the sample sizes of some foreign-born Asian ethnic groups, including Bhutanese, Mongolian, Nepalese, Cambodian, Hmong, Laotian, Thai, Bangladeshi, Burmese, Indonesian, and Malaysian are small; thus, these groups were lumped under "other Asians". Another limitation is that our sample captures only couples who remained in marriages but not those who were divorced or widowed. Nonetheless, because of the low divorce rates among Asians [40], the impact of divorce on the patterns of intermarriages was minor.

\subsection{Methods of Analysis}

For research question 1 on the dominant pattern of intermarriage among foreign-born Asians, we calculated the percentage distributions of interracial, interethnic, and intra-ethnic marriages among foreign-born Asian householders. To determine the type of marriages, a variable on the relationship to household head in conjunction with race and ethnicity was utilized. This variable describes a variety of family interrelationships among individuals within the same household. To answer research question 2 on ethnic differences in interracial and interethnic marriages among foreign-born Asians, we conducted cross-tabulation analyses and chi square tests among foreign-born Asian householders. To answer research question 3 on gender difference in intermarriage patterns among foreign-born Asians, we performed cross-tabulation analyses and chi square tests among foreign-born Asian householders. 


\section{Results}

This section reports the results on the dominant pattern of intermarriages among foreign-born Asians, patterns of intermarriages (interracial and interethnic) across different ethnic groups of foreign-born Asians, and gender differences in intermarriage patterns among foreign-born Asians.

\subsection{Dominant Patterns of Intermarriages}

Table 1 shows the frequency and percentage distributions of marriages between foreign-born Asian heads of household and their spouses from different racial and ethnic groups. Several patterns emerged from this table. First, the most dominant pattern of marriage among foreign-born Asian householders was intra-ethnic marriages, as $88.8 \%$ of foreign-born Asian householders married with their co-ethnics (e.g., Chinese with Chinese, Korean with Korean). Second, the dominant pattern of intermarriages was interracial marriages, primarily with whites. This was evident as $7.97 \%(=6.9+0.45+0.45+0.07+0.07)$ of foreign-born Asian householders married with non-Asians, compared to only 3.3\% who married with other Asians. Third, among the interracial marriages, the most common marriage was with whites (6.9\%) compared to $0.45 \%$ with black spouses, $0.45 \%$ with Hispanic spouses, $0.07 \%$ with Native American spouses, and $0.07 \%$ with Pacific Islander spouses.

Table 1. Intermarriage Patterns of Foreign-Born Asian Household Heads by Race or Ethnicity of Spouses, ACS 2008-2012.

\begin{tabular}{ccccccccc}
\hline $\begin{array}{c}\text { Foreign-Born } \\
\text { Asian Head of } \\
\text { Household }\end{array}$ & White & Black & Hispanic & $\begin{array}{c}\text { Native } \\
\text { American }\end{array}$ & $\begin{array}{c}\text { Pacific } \\
\text { Islander }\end{array}$ & Intra & Asian \\
Inter & Total \\
\hline$N$ & 8388 & 544 & 541 & 79 & 83 & 107,467 & 3940 & 121,042 \\
$\%$ & $(6.9)$ & $(0.45)$ & $(0.45)$ & $(0.07)$ & $(0.07)$ & $(88.8)$ & $(3.3)$ & $(100)$ \\
\hline
\end{tabular}

\subsection{Patterns of Intermarriages by Ethnicity}

How do different ethnic groups of foreign-born Asians differ in interracial and interethnic marriages? Table 2 shows the marriage patterns of foreign-born Asian household heads by Asian ethnicity. The $\chi^{2}$ test is highly significant, indicating significant differences in marriage pattern by Asian ethnicity.

Table 2. Intermarriage Patterns of Foreign-Born Asian Household Heads by Asian Ethnicity and by Race or Ethnicity of Spouses, American Community Surveys (ACS) 2008-2012.

\begin{tabular}{|c|c|c|c|c|c|c|c|c|}
\hline \multirow{3}{*}{$\begin{array}{l}\text { Foreign-Born } \\
\text { Asian Head of } \\
\text { Household }\end{array}$} & \multicolumn{8}{|c|}{ Race/Ethnicity of Spouse } \\
\hline & \multirow{2}{*}{ White } & \multirow[b]{2}{*}{ Black } & \multirow{2}{*}{ Hispanic } & \multirow{2}{*}{$\begin{array}{c}\text { Native } \\
\text { American }\end{array}$} & \multirow{2}{*}{$\begin{array}{l}\text { Pacific } \\
\text { Islander }\end{array}$} & \multicolumn{2}{|c|}{ Asian } & \multirow[b]{2}{*}{ Total } \\
\hline & & & & & & Intra & Inter & \\
\hline \multirow{2}{*}{ Chinese $^{1}$} & 1652 & 82 & 82 & 5 & 5 & 28,737 & 1240 & 31,803 \\
\hline & $(5.2)$ & $(0.3)$ & $(0.3)$ & $(0.0)$ & $(0.0)$ & $(90.0)$ & $(3.9)$ & $(100)$ \\
\hline \multirow{2}{*}{ Japanese } & 715 & 34 & 37 & 6 & 6 & 2490 & 490 & 3778 \\
\hline & (18.7) & $(0.9)$ & $(1.0)$ & $(0.2)$ & $(0.2)$ & $(66.0)$ & (13.0) & $(100)$ \\
\hline \multirow{2}{*}{ Filipino } & 2226 & 198 & 206 & 22 & 42 & 17,147 & 463 & 20,304 \\
\hline & (10.9) & $(1.0)$ & $(1.0)$ & $(0.1)$ & $(0.2)$ & $(83.9)$ & $(2.9)$ & $(100)$ \\
\hline \multirow{2}{*}{ Asian Indian } & 1385 & 103 & 70 & 16 & 15 & 27,520 & 334 & 29,443 \\
\hline & $(4.7)$ & $(0.3)$ & $(0.2)$ & $(0.1)$ & $(0.1)$ & $(93.2)$ & $(1.4)$ & $(100)$ \\
\hline \multirow{2}{*}{ Korean } & 995 & 42 & 40 & 13 & 4 & 10,643 & 306 & 12,043 \\
\hline & (8.2) & $(0.3)$ & $(0.3)$ & $(0.1)$ & $(0.0)$ & $(88.4)$ & $(2.5)$ & $(100)$ \\
\hline \multirow{2}{*}{ Vietnamese } & 538 & 25 & 37 & 6 & 3 & 12,247 & 443 & 13,299 \\
\hline & $(4.0)$ & $(0.2)$ & $(0.3)$ & $(0.0)$ & $(0.0)$ & (91.6) & $(3.9)$ & $(100)$ \\
\hline \multirow{2}{*}{ Pakistani } & 180 & 16 & 19 & 1 & 0 & 2472 & 94 & 2782 \\
\hline & (6.4) & $(0.6)$ & $(0.7)$ & $(0.0)$ & $(0.0)$ & $(88.1)$ & $(4.2)$ & $(100)$ \\
\hline \multirow{2}{*}{ Sri Lankan } & 31 & 4 & 0 & 0 & 0 & 381 & 16 & 432 \\
\hline & (7.1) & $(0.9)$ & $(0.0)$ & $(0.0)$ & $(0.0)$ & (87.6) & $(4.4)$ & (100) \\
\hline \multirow{2}{*}{ Other Asians 2} & 666 & 40 & 50 & 10 & 8 & 7226 & 554 & 7158 \\
\hline & (7.9) & $(0.5)$ & $(0.6)$ & $(0.1)$ & $(0.1)$ & $(85.4)$ & $(5.4)$ & $(100)$ \\
\hline Total & & & & & & & & 121,042 \\
\hline
\end{tabular}


Similar to the patterns of marriage for foreign-born Asian householders without breakdown by ethnicity shown in Table 1, the most dominant pattern of marriages for all foreign-born Asian ethnic groups was intra-ethnic marriage. This was evident as the majority of marriages occurred within the same ethnic group, ranging from $66 \%$ for Japanese to $93.2 \%$ for Asian Indians. In the same vein, the dominant pattern of intermarriages was interracial marriages, and predominantly with white spouses.

However, there were significant differences in intermarriage patterns among foreign-born Asian groups. Foreign-born Japanese householders were most likely to engage in interracial marriages, as $21 \%$ of Japanese householders were interracially married (including $18.7 \%$ of them with whites, $0.9 \%$ with blacks, $1 \%$ with Hispanics, $0.2 \%$ with Native Americans, and 0.2 with Pacific Islanders) compared to $13.2 \%$ of Filipinos, $9.2 \%$ of other Asians, $8.9 \%$ of Koreans, $8 \%$ of Sri Lankans, $7.7 \%$ of Pakistanis, $5.8 \%$ of Chinese, $5.4 \%$ of Asian Indians, and $4.5 \%$ of Vietnamese. As shown in Table 2, Japanese householders (13\%) were also most likely to marry interethnically with other Asian groups, while Asian Indian householders (1.4\%), Koreans (2.5\%) and Filipinos (2.9\%) were among the groups that were least likely to do so, and other Asians, Sri Lankans, Chinese, Pakistanis, and Vietnamese were somewhat in between.

Table 3 shows the patterns of interethnic marriages among Asian ethnic groups, based on data for foreign-born householders. Only eight out of 21 Asian ethnic groups are shown, including Chinese (Taiwanese included), Japanese, Filipino, Asian Indian, Korean, Vietnamese, Pakistani, and Sri Lankan. Bhutanese, Mongolian, Nepalese, Cambodian, Hmong, Laotian, Thai, Bangladeshi, Burmese, Indonesian, and Malaysian were lumped under other Asians because of their small sample sizes. It is evident that, compared to other Asian ethnicities, Japanese were most likely to marry interethnically, with a rate of $16.4 \%$ (sum of interethnic marriages for the Japanese row); within the $16.4 \%$, Japanese householders intermarried with the spouses of Chinese (5.4\%), Koreans (5.1\%), Filipinos (3.2\%), Vietnamese (1.3\%), other Asians (1.2\%), and Asian Indians $(0.2 \%)$ but not with the spouses of Pakistanis and Sri Lankans. Other Asian groups were fairly close in the rates of interethnic marriages (i.e., 5.1\% for other Asians, 4.1\% for Chinese, 4\% for Sri Lankans, 3.7\% for Pakistanis, 3.5\% for Vietnamese, 2.8\% for Koreans, 2.6\% for Filipinos, and 1.2\% for Asian Indians-the group with the lowest interethnic marriage rate), but none of them came close to the rate of Japanese. It is not surprising that East Asians (i.e., Japanese, Chinese, and Koreans) and Southeast Asians (e.g., Vietnamese and Filipinos) tended to marry one another and that South Asians (i.e., Asian Indians, Pakistanis, and Sri Lankans) married one another. 
Table 3. Patterns of Intermarriages among Foreign-Born Asian Groups by Foreign-Born Household Heads and Foreign-Born Spouses, ACS $2008-2012$.

\begin{tabular}{|c|c|c|c|c|c|c|c|c|c|c|}
\hline \multirow{2}{*}{$\begin{array}{c}\text { Foreign-Born } \\
\text { Household Head }\end{array}$} & \multicolumn{10}{|c|}{ Foreign-Born Spouse } \\
\hline & Chinese $^{1}$ & Japanese & Filipino & Asian Indian & Korean & Vietnamese & Pakistani & Sri Lankan & Other Asians ${ }^{2}$ & Total \\
\hline Chinese $^{1}$ & $\begin{array}{l}28,737 \\
(95.9)\end{array}$ & $\begin{array}{c}222 \\
(0.7)\end{array}$ & $\begin{array}{l}230 \\
(0.8)\end{array}$ & $\begin{array}{l}110 \\
(0.4)\end{array}$ & $\begin{array}{l}245 \\
(0.8)\end{array}$ & $\begin{array}{l}278 \\
(0.9)\end{array}$ & $\begin{array}{c}3 \\
(0.0)\end{array}$ & 2 & 150 & 29,977 \\
\hline \multirow{2}{*}{ Japanese } & $\begin{array}{c}(95.9) \\
161\end{array}$ & $\begin{array}{l}(0.7) \\
2490\end{array}$ & $\begin{array}{c}(0.8) \\
95\end{array}$ & $\begin{array}{c}(0.4) \\
6\end{array}$ & $\begin{array}{l}(0.8) \\
151\end{array}$ & $\begin{array}{c}(0.9) \\
39\end{array}$ & $\begin{array}{c}(0.0) \\
0\end{array}$ & $\begin{array}{c}(0.0) \\
0\end{array}$ & $\begin{array}{c}(0.5) \\
38\end{array}$ & $\begin{array}{l}(26.6) \\
2980\end{array}$ \\
\hline & $(5.4)$ & (83.6) & $(3.2)$ & $(0.2)$ & (5.1) & (1.3) & $(0.0)$ & $(0.0)$ & (1.3) & $(2.6)$ \\
\hline \multirow{2}{*}{ Filipino } & 139 & 93 & 17,147 & 32 & 57 & 46 & 4 & 0 & 92 & 17,610 \\
\hline & $(0.8)$ & $(0.5)$ & (97.4) & $(0.2)$ & $(0.3)$ & $(0.3)$ & $(0.0)$ & $(0.0)$ & $(0.5)$ & (15.6) \\
\hline Asian Indian & 81 & 20 & 65 & 27,520 & 12 & 16 & 73 & 7 & 60 & 27,854 \\
\hline \multirow{2}{*}{ Korean } & 134 & 62 & 44 & 8 & 10,643 & 36 & 0 & 0 & 22 & 10,949 \\
\hline & $(1.2)$ & $(0.6)$ & $(0.4)$ & $(0.1)$ & $(97.2)$ & $(0.3)$ & $(0.0)$ & $(0.0)$ & $(0.2)$ & $(9.7)$ \\
\hline \multirow{2}{*}{ Vietnamese } & 211 & 23 & 66 & 5 & 45 & 12,247 & 2 & 1 & 90 & 12,690 \\
\hline & (1.7) & $(0.2)$ & $(0.5)$ & $(0.0)$ & $(0.4)$ & (96.5) & $(0.0)$ & $(0.0)$ & $(0.7)$ & (11.3) \\
\hline \multirow{2}{*}{ Pakistani } & 5 & 0 & 17 & 45 & 1 & 2 & 2472 & 3 & 21 & 2566 \\
\hline & $(0.2)$ & $(0.0)$ & $(0.7)$ & (1.8) & $(0.0)$ & $(0.1)$ & (96.3) & $(0.1)$ & (0.8) & (2.3) \\
\hline \multirow{2}{*}{ Sri Lankan } & 0 & 3 & 3 & 5 & 0 & 1 & 0 & 381 & 4 & 397 \\
\hline & $(0.0)$ & $(0.8)$ & (0.8) & (1.3) & $(0.0)$ & $(0.3)$ & $(0.0)$ & (96.0) & (1.0) & (0.4) \\
\hline \multirow{2}{*}{ Other Asians } & 48 & 4 & 23 & 16 & 7 & 20 & 14 & 0 & 7226 & 7358 \\
\hline & (1.6) & (0.4) & (1.1) & (0.4) & (0.3) & (1.1) & $(0.3)$ & $(0.0)$ & (94.9) & (6.8) \\
\hline
\end{tabular}

include Taiwanese. ${ }^{2}$ Other Asians include Bhutanese, Mongolian, Nepalese, Cambodian, Hmong, Laotian, Thai, Bangladeshi, Burmese, Indonesian, and Malaysian. 


\subsection{Patterns of Intermarriages by Gender}

The analysis of intermarriage patterns among foreign-born Asians would be incomplete without considering gender, because gender has great impact on the patterns. Table 4 displays the frequency and percentage distributions of marriages for foreign-born Asian heads of household by gender. One gender difference was that foreign-born Asian male householders were more likely to intra-marry than their foreign-born female counterparts, as the male intra-marriage rate was $91.8 \%$, compared to the female intra-marriage rate of $78.7 \%$. Another gender difference was that foreign-born Asian female householders were more likely to interracially marry with spouses of all other non-Asian groups than foreign-born Asian male householders. In particular, foreign-born Asian female householders were more likely to marry white spouses (15.3\%) than their foreign-born male counterparts $(4.7 \%)$. The gender difference in interethnic marriage rate was small with $3.6 \%$ for female householders versus $3.0 \%$ for male householders.

Table 4. Intermarriage Patterns of Foreign-Born Asian Household Heads by Race or Ethnicity of Spouses and by Sex, ACS 2008-2012.

\begin{tabular}{|c|c|c|c|c|c|c|c|c|c|}
\hline \multirow{3}{*}{\multicolumn{2}{|c|}{$\begin{array}{l}\text { Foreign-Born } \\
\text { Asian Head of } \\
\text { Household }\end{array}$}} & \multicolumn{8}{|c|}{ Race/Ethnicity of Spouse } \\
\hline & & \multirow{2}{*}{ White } & \multirow{2}{*}{ Black } & \multirow{2}{*}{ Hispanic } & \multirow{2}{*}{$\begin{array}{c}\text { Native } \\
\text { American }\end{array}$} & \multirow{2}{*}{$\begin{array}{l}\text { Pacific } \\
\text { Islander }\end{array}$} & \multicolumn{2}{|c|}{ Asian } & \multirow{2}{*}{ Total } \\
\hline & & & & & & & Intra & Inter & \\
\hline \multirow[t]{2}{*}{ Male } & \# & 4053 & 149 & 323 & 52 & 57 & 85,171 & 2919 & 92,724 \\
\hline & $\%$ & $(4.7)$ & $(0.2)$ & $(0.3)$ & $(0.0)$ & $(0.0)$ & $(91.8)$ & $(3.0)$ & $(100)$ \\
\hline \multirow[t]{2}{*}{ Female } & \# & 4335 & 395 & 218 & 27 & 26 & 22,296 & 1021 & 28,318 \\
\hline & $\%$ & $(15.3)$ & $(1.4)$ & $(0.8)$ & $(0.1)$ & $(0.1)$ & $(78.7)$ & $(3.6)$ & $(100)$ \\
\hline
\end{tabular}

Nevertheless, there are large variations across foreign-born Asian groups in gender differences in intermarriage patterns. Table 5 shows the patterns of intermarriages based on foreign-born Asian householders by gender among Asian groups. One pattern was that, for almost all Asian groups, foreign-born male householders were more likely to marry within their ethnic group than foreign-born female householders. However, there was virtually no gender difference for Pakistani householders; in fact, Pakistani female householders (90\%) were slightly more likely to marry within their ethnicity than Pakistani male householders (88.6\%). Furthermore, foreign-born Japanese male householders $(74.4 \%)$ were more than twice as likely as foreign-born Japanese female householders (34.4\%) to marry within their ethnicity, but foreign-born Asian Indian male householders (94\%) were only 3.9\% more likely than their foreign-born female householders $(90.1 \%)$ to do so and other groups were in between, with large variations in rates.

Another pattern was the contrast between Japanese and other Asian ethnic groups in the gendered dominant marriage pattern. For foreign-born Japanese female householders, the dominant marriage pattern was interracial marriage, as $54.7 \%$ of foreign-born Japanese female householders married non-Asians, but for their male counterparts intra-marriage remained the dominant marriage pattern. For other Asian ethnicities, intra-marriage remained the dominant marriage pattern, but the interracial marriage rates varied between men and women. Adding the interracial marriage rates up for each row reveals that $23.8 \%$ of foreign-born Korean female householders were interracially married compared to $3.9 \%$ foreign-born Korean male householders; $23.3 \%$ of foreign-born Filipino female householders were interracially married compared to $8 \%$ foreign-born Filipino male householders; $23.7 \%$ of foreign-born other Asian female householders were interracially married compared to $7 \%$ foreign-born other Asian male householders; $13.4 \%$ of foreign-born Chinese female householders were interracially married compared to $3.2 \%$ foreign-born Chinese male householders; $12.2 \%$ of foreign-born Sri Lankan female householders were interracially married compared to 7.1\% foreign-born Sri Lankan male householders; $11.8 \%$ of foreign-born Vietnamese female householders were interracially married compared to $2.6 \%$ foreign-born Vietnamese male householders; 8.3\% of foreign-born Asian Indian female householders were interracially married compared to $4.9 \%$ foreign-born Asian Indian male householders; and 5.6\% of 
foreign-born Pakistani female householders were interracially married compared to $8.2 \%$ foreign-born Pakistani male householders.

Table 5. Intermarriage Patterns of Foreign-Born Asian Household Heads by Sex and by Race or Ethnicity of Spouses, ACS 2008-2012.

\begin{tabular}{|c|c|c|c|c|c|c|c|c|}
\hline \multirow{3}{*}{$\begin{array}{l}\text { Foreign-Born } \\
\text { Asian Heads of } \\
\text { Household }\end{array}$} & \multicolumn{8}{|c|}{ Race/Ethnicity of Spouses } \\
\hline & \multirow{2}{*}{ White } & \multirow{2}{*}{ Black } & \multirow{2}{*}{ Hispanic } & \multirow{2}{*}{$\begin{array}{l}\text { Native } \\
\text { American }\end{array}$} & \multirow{2}{*}{$\begin{array}{l}\text { Pacific } \\
\text { Islander }\end{array}$} & \multicolumn{2}{|c|}{ Asian } & \multirow[b]{2}{*}{ Total } \\
\hline & & & & & & Intra & Inter & \\
\hline \multicolumn{9}{|l|}{ Chinese $^{1}$} \\
\hline Male & $\begin{array}{l}706 \\
(29)\end{array}$ & $\begin{array}{c}30 \\
(0.1)\end{array}$ & $\begin{array}{c}48 \\
(0.2)\end{array}$ & $\begin{array}{c}5 \\
(0.0)\end{array}$ & $\begin{array}{c}2 \\
(0.0)\end{array}$ & $\begin{array}{l}22,341 \\
(927)\end{array}$ & $\begin{array}{r}959 \\
(4.0)\end{array}$ & $\begin{array}{c}24,091 \\
(100)\end{array}$ \\
\hline Female & $\begin{array}{c}946 \\
(12.3)\end{array}$ & $\begin{array}{c}52 \\
(0.7)\end{array}$ & $\begin{array}{c}34 \\
(0.4)\end{array}$ & $\begin{array}{c}0 \\
(0.0)\end{array}$ & $\begin{array}{c}3 \\
(0.0)\end{array}$ & $\begin{array}{c}6396 \\
(82.9)\end{array}$ & $\begin{array}{l}281 \\
(3.6)\end{array}$ & $\begin{array}{l}7714 \\
(100)\end{array}$ \\
\hline \multicolumn{9}{|l|}{ Japanese } \\
\hline Male & $\begin{array}{c}326 \\
(10.9)\end{array}$ & $\begin{array}{c}4 \\
(0.1)\end{array}$ & $\begin{array}{c}23 \\
(0.8)\end{array}$ & $\begin{array}{c}5 \\
(0.2)\end{array}$ & $\begin{array}{c}3 \\
(0.1)\end{array}$ & $\begin{array}{c}2215 \\
(74.4)\end{array}$ & $\begin{array}{c}402 \\
(13.5)\end{array}$ & $\begin{array}{l}2978 \\
(100)\end{array}$ \\
\hline Female & $\begin{array}{c}389 \\
(48.6)\end{array}$ & $\begin{array}{c}30 \\
(3.8)\end{array}$ & $\begin{array}{c}14 \\
(1.8)\end{array}$ & $\begin{array}{c}1 \\
(0.1)\end{array}$ & $\begin{array}{c}3 \\
(0.4)\end{array}$ & $\begin{array}{c}275 \\
(34.4)\end{array}$ & $\begin{array}{c}88 \\
(11.0)\end{array}$ & $\begin{array}{c}800 \\
(100)\end{array}$ \\
\hline \multicolumn{9}{|l|}{ Filipino } \\
\hline Male & $\begin{array}{c}905 \\
(6.8)\end{array}$ & $\begin{array}{c}20 \\
(0.2)\end{array}$ & $\begin{array}{c}97 \\
(0.7)\end{array}$ & $\begin{array}{c}12 \\
(0.1)\end{array}$ & $\begin{array}{c}27 \\
(0.2)\end{array}$ & $\begin{array}{l}11,977 \\
(89.9)\end{array}$ & $\begin{array}{l}282 \\
(2.1)\end{array}$ & $\begin{array}{c}13,320 \\
(100)\end{array}$ \\
\hline Female & $\begin{array}{c}1321 \\
(18.9)\end{array}$ & $\begin{array}{l}178 \\
(2.5)\end{array}$ & $\begin{array}{l}109 \\
(1.6)\end{array}$ & $\begin{array}{c}10 \\
(0.1)\end{array}$ & $\begin{array}{c}15 \\
(0.2)\end{array}$ & $\begin{array}{l}5170 \\
(74)\end{array}$ & $\begin{array}{c}181 \\
(2.6)\end{array}$ & $\begin{array}{l}6984 \\
(100)\end{array}$ \\
\hline \multicolumn{9}{|l|}{ Asian Indian } \\
\hline Male & $\begin{array}{l}1060 \\
(4.3)\end{array}$ & $\begin{array}{c}53 \\
(0.2)\end{array}$ & $\begin{array}{c}55 \\
(0.2)\end{array}$ & $\begin{array}{c}13 \\
(0.1)\end{array}$ & $\begin{array}{c}15 \\
(0.1)\end{array}$ & $\begin{array}{c}23,236 \\
(94.0)\end{array}$ & $\begin{array}{c}276 \\
(1.1)\end{array}$ & $\begin{array}{c}24,708 \\
(100)\end{array}$ \\
\hline Female & $\begin{array}{c}325 \\
(6.8) \\
\end{array}$ & $\begin{array}{c}50 \\
(1.1) \\
\end{array}$ & $\begin{array}{c}15 \\
(0.3) \\
\end{array}$ & $\begin{array}{c}3 \\
(0.1) \\
\end{array}$ & $\begin{array}{c}0 \\
(0.0) \\
\end{array}$ & $\begin{array}{c}4284 \\
(90.1) \\
\end{array}$ & $\begin{array}{c}58 \\
(1.2) \\
\end{array}$ & $\begin{array}{l}4,735 \\
(100)\end{array}$ \\
\hline \multicolumn{9}{|l|}{ Korean } \\
\hline Male & $\begin{array}{l}304 \\
(3.4)\end{array}$ & $\begin{array}{c}9 \\
(0.1)\end{array}$ & $\begin{array}{c}27 \\
(0.3)\end{array}$ & $\begin{array}{c}5 \\
(0.1)\end{array}$ & $\begin{array}{c}2 \\
(0.0)\end{array}$ & $\begin{array}{c}8357 \\
(93.9)\end{array}$ & $\begin{array}{l}195 \\
(2.2)\end{array}$ & $\begin{array}{l}8899 \\
(100)\end{array}$ \\
\hline Female & $\begin{array}{c}691 \\
(21.9)\end{array}$ & $\begin{array}{c}33 \\
(1.1)\end{array}$ & $\begin{array}{c}13 \\
(0.4)\end{array}$ & $\begin{array}{c}8 \\
(0.3)\end{array}$ & $\begin{array}{c}2 \\
(0.1)\end{array}$ & $\begin{array}{l}2286 \\
(72.7)\end{array}$ & $\begin{array}{c}111 \\
(3.5)\end{array}$ & $\begin{array}{l}3144 \\
(100)\end{array}$ \\
\hline \multicolumn{9}{|l|}{ Vietnamese } \\
\hline Male & $\begin{array}{l}239 \\
(2.3)\end{array}$ & $\begin{array}{c}8 \\
(0.1)\end{array}$ & $\begin{array}{c}23 \\
(0.2)\end{array}$ & $\begin{array}{c}4 \\
(0.0)\end{array}$ & $\begin{array}{c}2 \\
(0.0)\end{array}$ & $\begin{array}{c}9907 \\
(94.4)\end{array}$ & $\begin{array}{c}317 \\
(3.0)\end{array}$ & $\begin{array}{c}10,500 \\
(100)\end{array}$ \\
\hline Female & $\begin{array}{c}299 \\
(10.6) \\
\end{array}$ & $\begin{array}{c}17 \\
(0.6) \\
\end{array}$ & $\begin{array}{c}14 \\
(0.5) \\
\end{array}$ & $\begin{array}{c}2 \\
(0.1) \\
\end{array}$ & $\begin{array}{c}1 \\
(0.0) \\
\end{array}$ & $\begin{array}{r}2340 \\
(83.6) \\
\end{array}$ & $\begin{array}{c}126 \\
(4.5) \\
\end{array}$ & $\begin{array}{l}2799 \\
(100) \\
\end{array}$ \\
\hline \multicolumn{9}{|l|}{ Pakistani } \\
\hline Male & $\begin{array}{l}162 \\
(7)\end{array}$ & $\begin{array}{c}9 \\
(0.4)\end{array}$ & $\begin{array}{c}19 \\
(0.8)\end{array}$ & $\begin{array}{c}1 \\
(0.0)\end{array}$ & $\begin{array}{c}0 \\
(0.0)\end{array}$ & $\begin{array}{c}2074 \\
(88.6)\end{array}$ & $\begin{array}{c}75 \\
(3.2)\end{array}$ & $\begin{array}{l}2340 \\
(100)\end{array}$ \\
\hline Female & $\begin{array}{c}18 \\
(4.0) \\
\end{array}$ & $\begin{array}{c}7 \\
(1.6) \\
\end{array}$ & $\begin{array}{c}0 \\
(0.0) \\
\end{array}$ & $\begin{array}{c}0 \\
(0.0) \\
\end{array}$ & $\begin{array}{c}0 \\
(0.0) \\
\end{array}$ & $\begin{array}{c}398 \\
(90.0) \\
\end{array}$ & $\begin{array}{c}19 \\
(4.2)\end{array}$ & $\begin{array}{c}442 \\
(100)\end{array}$ \\
\hline \multicolumn{9}{|l|}{ Sri Lankan } \\
\hline Male & $\begin{array}{c}21 \\
(6.0)\end{array}$ & $\begin{array}{c}4 \\
(1.1)\end{array}$ & $\begin{array}{c}0 \\
(0.0)\end{array}$ & $\begin{array}{c}0 \\
(0.0)\end{array}$ & $\begin{array}{c}0 \\
(0.0)\end{array}$ & $\begin{array}{c}313 \\
(90.0)\end{array}$ & $\begin{array}{c}12 \\
(3.4)\end{array}$ & $\begin{array}{c}350 \\
(100)\end{array}$ \\
\hline Female & $\begin{array}{c}10 \\
(12.2) \\
\end{array}$ & $\begin{array}{c}0 \\
(0.0) \\
\end{array}$ & $\begin{array}{c}0 \\
(0.0) \\
\end{array}$ & $\begin{array}{c}0 \\
(0.0) \\
\end{array}$ & $\begin{array}{c}0 \\
(0.0) \\
\end{array}$ & $\begin{array}{c}68 \\
(83.0) \\
\end{array}$ & $\begin{array}{c}4 \\
(4.9) \\
\end{array}$ & $\begin{array}{c}82 \\
(100) \\
\end{array}$ \\
\hline \multicolumn{9}{|l|}{ Other Asians ${ }^{2}$} \\
\hline Male & $\begin{array}{c}330 \\
(6.0)\end{array}$ & $\begin{array}{c}12 \\
(0.2)\end{array}$ & $\begin{array}{c}31 \\
(0.6)\end{array}$ & $\begin{array}{c}7 \\
(0.1)\end{array}$ & $\begin{array}{c}6 \\
(0.1)\end{array}$ & $\begin{array}{c}4751 \\
(85.8)\end{array}$ & $\begin{array}{l}401 \\
(7.2)\end{array}$ & $\begin{array}{c}5538 \\
(100)\end{array}$ \\
\hline Female & $\begin{array}{c}336 \\
(20.7)\end{array}$ & $\begin{array}{c}28 \\
(1.7)\end{array}$ & $\begin{array}{c}19 \\
(1.0)\end{array}$ & $\begin{array}{c}3 \\
(0.2)\end{array}$ & $\begin{array}{c}2 \\
(0.1)\end{array}$ & $\begin{array}{c}1079 \\
(66.6)\end{array}$ & $\begin{array}{l}153 \\
(9.4)\end{array}$ & $\begin{array}{l}1620 \\
(100)\end{array}$ \\
\hline
\end{tabular}

Note: All $\chi^{2}$ tests are highly significant at the 0.001 level or beyond. Percentages are in parentheses. ${ }^{1}$ Chinese include Taiwanese. ${ }^{2}$ Other Asians include Bhutanese, Mongolian, Nepalese, Cambodian, Hmong, Laotian, Thai, Bangladeshi, Burmese, Indonesian, and Malaysian.

The third pattern was that, except for Pakistanis, for all other Asian groups foreign-born female householders were much more likely to marry white spouses than their foreign-born male counterparts. This was especially true for Japanese ( $48.6 \%$ for females vs. $10.9 \%$ for males), Koreans $(21.9 \%$ for females vs. $3.4 \%$ for males), and Filipinos (18.9\% for females vs. $6.8 \%$ for males). For Pakistanis, 
the reverse was evident, as $7 \%$ of male Pakistani householders married whites, compared to $4 \%$ of female Pakistani householders.

Finally, the gender differences in interethnic marriage rate were generally small across all Asian groups. The biggest difference was $2.5 \%$ for Japanese.

\section{Discussion and Conclusions}

In an effort to fill the void in the literature, this study examines the patterns of intermarriages among foreign-born Asians using data from ACS 2008-2012. One of the key findings of this study is that for foreign-born Asians as a whole based on the data of foreign-born Asian heads of household, while intra-ethnic marriage remained as the most dominant pattern of marriages among foreign-born Asians, the dominant pattern of intermarriages was interracial marriages, primarily with whites, rather than interethnic marriages. In fact, inter-Asian marriages only made up about $3 \%$ of all foreign-born Asian marriages at the national level.

Nevertheless, significant variations existed among foreign-born Asian ethnic groups. The findings reveal that, despite similarities across Asian ethnic groups in intra-ethnic marriages as the dominant marriage pattern and the preponderance of interracial marriages over interethnic marriages, foreign-born Japanese were far more likely to engage in interracial marriages than any other foreign-born Asian groups. Foreign-born Filipinos, Koreans, and other Asians also had relatively high interracial marriage rates. Foreign-born Asian Indians appeared to have the lowest rates of interracial marriages.

In addition, foreign-born Japanese were more likely to interethnically marry, especially with Chinese, Koreans, and Filipinos, than other foreign-born Asian groups. The high rate of intermarriage among foreign-born Japanese may be explained by the fact that many foreign-born Japanese came initially as students or temporary workers and later married with non-Japanese in the U.S. [41]. In the other extreme, Asian Indians were least likely to interethnically marry. East Asians (i.e., Japanese, Chinese, and Koreans) and Southeast Asians (e.g., Vietnamese and Filipinos) were more likely to marry one another, while South Asians (i.e., Asian Indians, Pakistanis, and Sri Lankans) tended to marry one another.

Foreign-born Asian men were more likely to engage in intra-marriage than foreign-born Asian women. On the other hand, foreign-born Asian women were more likely to interracially marry, especially with whites, than their foreign-born Asian male counterparts; however, men and women were not much different in the rate of interethnic marriages. For both foreign-born females and foreign-born males, intramarriages were still the norm.

Our findings document for the first time using nationally representative samples of ACS 2008-2012 that interracial marriage rather than interethnic marriage has remained the current dominant pattern of intermarriages for foreign-born Asians at the national level. Hence, the supersession of interracial marriage by interethnic marriage detected among Asian Americans in California in 1990 by Shinagawa and Pang [24] remained a state phenomenon for all Asians en masse. This supersession has not materialized among Asian immigrants as documented in the current study, among U.S.-born Asians found in Min and Kim's [14] study, or among all Asian Americans. For foreign-born Asians collectively, the level of inter-Asian marriages was very low at about 3\% in 2008-2012. This is consistent with the finding of Bohra-Mishra and Massey [16], based on a small sample of new Asian immigrants. A large influx of new immigrants from major Asian groups in the last two to three decades and their strong transnational ties with the homelands may have contributed to the low inter-Asian marriages. It is not very likely that interethnic marriage will replace interracial marriage among foreign-born Asians or Asian Americans anytime soon.

Our findings also uncover that, although foreign-born Asian women are more likely to interracially marry than foreign-born Asian men, there was little difference between foreign-born Asian women and foreign-born Asian men in interethnic marriage rates. This finding is novel and can be detected only by differentiating between interracial marriage and interethnic marriage. Hence, it is erroneous to make a sweeping claim that foreign-born Asian women are more likely to engage in 
intermarriage than foreign-born Asian men; this statement is valid for interracial marriage but invalid for interethnic marriage.

Our results provide fresh insights into who foreign-born Asians intermarry with and at what rates, contrary to most existing studies of Asian intermarriages that are confined to exogamous or endogamous rates. We show that the interracial marriage rates with whites were much higher than those with other non-Asian groups. When it comes to interethnic marriages, we also offer detailed information about which foreign-born Asian group tended to marry which foreign-born Asian groups.

Our findings based on the 2008-2012 ACS data confirm the findings of Lee and Fernandez [12] and Lee and Boyd [11] using the PUMS data from the 1980, 1990, and 2000 censuses that foreign-born Japanese had the highest rates of intermarriages, foreign-born Asian Indians had the lowest rates of interracial marriages, and other foreign-born Asian groups (e.g., Filipinos, Koreans, other Asians, Chinese) fell somewhat in between, but we provide breakdown information by interracial marriages and interethnic marriages. Our results also corroborate the findings of Lee and Fernandez [12] that for foreign-born Asian groups women were generally more likely to interracially marry than men, with the exception of foreign-born Asian Indians who displayed an opposite pattern. Our findings of marriage patterns are consistent with the findings of Fujino's study of interracial dating among Asian American college students [42] that Asian American women preferred to date and marry their coethnics, followed by whites and then other Asians. However, her finding that the dating and marriage preference order for Asian American men was their coethnics, other Asians, and then whites is somewhat different from ours.

Our findings also have significant implications for assimilation and Asian American panethnicity. Our data on interracial and interethnic marriage rates reveal two types of integration into American society for foreign-born Asians: integration into mainstream American society and integration into Asian American panethnic group and identity. Although both types of integration are transpiring, the evidence for the former seems to be somewhat stronger than that for the latter. Our finding of a very low level in interethnic marriages among Asian groups suggests that the impact of interethnic marriages on Asian American panethnicity is quite limited currently and in the foreseeable future at the national level. This result calls for a realistic understanding of the challenge for Asian American panethnicity and appropriate strategies for it. However, our finding does not imply that interethnic marriages have no significant impact on Asian American panethnicity at the state or local level where Asians are concentrated, such as California [24]. On the other hand, the finding of a continuous dominant pattern of interracial marriages with whites among foreign-born Asians points to the possibility of blurring racial line in the future. Nonetheless, the possibility for Asian Americans to become white in the near future may remain remote [43].

This study makes unique contributions to the literature by analyzing the patterns of interracial and interethnic marriages among foreign-born Asians and by documenting the dominant intermarriage patterns among foreign-born Asians as a whole, by ethnicity, and by gender, using the latest national-level data. While the focus of this study is the patterns of intermarriages among foreign-born Asians, this article has not fully addressed the determinants of intermarriages among foreign-born Asians because of space constraint. Many other factors could influence interracial and interethnic marriages among foreign-born Asians, including, but not limited to, status inconsistency, assimilation, stereotype or prejudice, and internal migration. Insufficient research has examined the determinants of intermarriages among foreign-born Asians, U.S.-born Asians, or Asian Americans as a whole. It is important to analyze the determinants of intermarriages, so that we can understand why intermarriages take place. A comparative study of interracial and interethnic marriage patterns and determinants between foreign-born Asians and native-born Asians is also worth undertaking.

Author Contributions: Both P.Y. and M.B. were involved in the selection of the research topic and research design. P.Y. recommended the data and methods of analysis. M.B. extracted the data, performed computer data analysis, and drafted the initial paper. P.Y. revised and edited the paper. P.Y. did additional revisions during the peer-review process and completed the final manuscript. All authors approved the final manuscript. 
Funding: This research received no external funding.

Acknowledgments: An earlier version of this paper was presented at the 2017 Asia-Pacific Conference in Social Sciences and Management, Taipei, Taiwan, in March 2017.

Conflicts of Interest: The authors declare no conflicts of interest.

\section{References and Notes}

1. Gordon, M. Assimilation in American Life; Oxford University Press: New York, NY, USA, 1964.

2. Qian, Z.; Blair, S.; Ruf, S. Asian American Interracial and Interethnic Marriages: Differences by Education and Nativity. Int. Migr. Rev. 2001, 35, 557-586. [CrossRef]

3. Espiritu, Y. Asian American Panethnicity: Bridging Institutions and Identities; Temple University Press: Philadelphia, PA, USA, 1992.

4. Lopez, D.; Espiritu, Y. Panethnicity in the United States: A Theoretical Framework. Ethn. Racial Stud. 1990, 13, 198-224. [CrossRef]

5. Lee, S. Asian Americans: Diverse and Growing. Popul. Bull. 1998, 53, 1-40. [PubMed]

6. PEW Research. The Rise of Asian Americans: Updated Edition April 04, 2013. Available online: http: / / www.pewsocialtrends.org/2012/06/19/the-rise-of-asian-americans/ (accessed on 18 October 2016).

7. Yang, P.Q. Asian Immigration to the United States; Polity Press: Malden, MA, USA, 2011.

8. Fu, X.; Hatfield, M. Intermarriage and Segmented Assimilation: U.S.-Born Asians in 2000. J. Asian Am. Stud. 2008, 11, 249-277.

9. Hwang, S.; Saenz, R.; Aguirre, B. The SES Selectivity of Interracially Married Asians. Int. Migr. Rev. 1995, 29, 469-491. [CrossRef]

10. Hwang, S.; Saenz, R.; Aguirre, B. Structural and Assimilationist Explanations of Asian American Intermarriage. J. Marriage Fam. 1997, 59, 758-772. [CrossRef]

11. Lee, S.; Boyd, M. Marrying Out: Comparing the Marital and Social Integration of Asians in the US and Canada. Soc. Sci. Res. 2008, 38, 311-329. [CrossRef]

12. Lee, S.; Fernandez, M. Trends in Asian American Racial/Ethnic Intermarriage: A Comparison of 1980 and 1990 Census Data. Sociol. Perspect. 1998, 42, 323-342. [CrossRef]

13. Lee, S.; Yamanaka, K. Patterns of Asian American Intermarriage and Marital Assimilation. J. Comp. Fam. Stud. 1990, 21, 287-305.

14. Min, P.G.; Kim, C. Patterns of Intermarriages and Cross-Generational In-marriages among Native-Born Asian Americans. Int. Migr. Rev. 2009, 43, 447-470. [CrossRef]

15. Okamoto, D. Marrying Out: A Boundary Approach to Understanding the Marital Integration of Asian Americans. Soc. Sci. Res. 2007, 36, 1391-1414. [CrossRef]

16. Bohra-Mishra, P.; Massey, D. Intermarriage among New Immigrants in the USA. Ethn. Racial Stud. 2015, 38, 734-758. [CrossRef] [PubMed]

17. U.S. Citizenship and Immigration Service. Yearbook of Immigration Statistics, Various Years. Available online: https: / / www.dhs.gov/immigration-statistics/yearbook (accessed on 28 March 2018).

18. Kitano, L.; Chai, L. Korean Interracial Marriage. Marriage Fam. Rev. 1982, 5, 75-90. [CrossRef]

19. Kitano, L.; Yeung, W.T.; Chai, L.; Hatanaka, H. Asian American Interracial Marriage. J. Marriage Fam. 1984, 46, 179-190. [CrossRef]

20. Ono, H.; Berg, J. Homogamy and Intermarriage of Japanese and Japanese Americans with Whites Surrounding World War II. J. Marriage Fam. 2010, 72, 1249-1262. [CrossRef] [PubMed]

21. Passel, J.; Wang, W.; Taylor, P. Marrying Out: One-in-Seven New U.S. Marriages Is Interracial or Interethnic; Pew Research Center: Washington, DC, USA, 2010.

22. Wang, W. The Rise of Intermarriage: Rates, Characteristics Vary by Race and Gender; Pew Research Center: Washington, DC, USA, 2012.

23. Yang, P.Q. Future Prospects of Asian Americans. In Asian Americans: Contemporary Trends and Issues, 2nd ed.; Min, P.G., Ed.; Sage: Thousand Oaks, CA, USA, 2006; pp. 292-316. ISBN 141-290-556-7.

24. Shinagawa, L.; Pang, G.Y. Asian American Panethnicity and Intermarriage. Amerasia J. 1996, 22, $127-152$. [CrossRef]

25. Spickard, P. Mixed Blood: Intermarriage and Ethnic Identity in Twentieth Century America; University of Wisconsin Press: Madison, WI, USA, 1989. 
26. Wong, M. A Look at Intermarriage among the Chinese in the U.S. in 1980. Sociol. Perspect. 1989, 32, 87-107. [CrossRef]

27. Chan, S. Asian Americans: An Interpretive History; Twayne: Boston, MA, USA, 1991.

28. Hing, B.O. Making and Remaking Asian America through Immigration Policy, 1850-1990; Stanford University Press: Stanford, CA, USA, 1993.

29. Kitano, L. Asian American: Emerging Minorities; Prentice-Hall: Englewood Cliffs, NJ, USA, 1988.

30. Takaki, R. Strangers from a Different Shore: A History of Asian Americans; Little Brown and Company: New York, NY, USA, 1989.

31. Lee, S.; Edmonston, B. New Marriages, New Families: U.S. Racial and Hispanic Intermarriage. Popul. Bull. 2005, 60, 1-36.

32. Shukert, E.; Scibetta, B. War Brides of WWII; Presideo Press: Novato, CA, USA, 1988.

33. Nesteruk, O.; Gramescu, A. Dating and Mate Selection among Young Adults from Immigrant Families. Marriage Fam. Rev. 2012, 48, 40-58. [CrossRef]

34. Min, P.G. Korean Immigrants' Marital Patterns and Marital Adjustments. In Family Ethnicity: Strength in Diversity; McAdoo, H., Ed.; Sage: Newburry Park, CA, USA, 1993; pp. 277-292. ISBN 076-191-857-4.

35. Min, P.G.; Kim, C. The Intergenerational Differences in Marital Patterns among Korean Americans. In Second-Generation Korean Experiences in the United States and Canada; Min, P.G., Noh, S., Eds.; Lexington Books: Lanham, MD, USA, 2014; pp. 75-86. ISBN 978-1-4985-0353-2.

36. Hwang, S.; Saenz, R.; Aguirre, B. Structural and Individual Determinants of Outmarriage among Chinese, Filipino, and Japanese Americans in California. Sociol. Inq. 1994, 64, 396-414. [CrossRef]

37. Qian, Z.; Lichter, D. Social Boundaries and Marital Assimilation: Interpreting Trends in Racial and Ethnic Intermarriage. Am. Sociol. Rev. 2007, 72, 68-94. [CrossRef]

38. IPUMS-USA. Available online: https://usa.ipums.org/usa (accessed on 1 September 2015). 2008-2012 ACS 5-Year PUMS Data Dictionary, IPUMS USA. Available online: https:/ / usa.ipums.org/usa/resources/ codebooks/DataDict0812.pdf (accessed on 1 September 2015).

39. For brevity and clarity, we present the results based on the sample of foreign-born Asian householders who were married with the spouse present. However, we repeated the analysis using the sample of foreign-born Asian spouses who were married with the spouse present. The findings are by and large consistent with the results presented here, albeit with some relatively minor variations. The results are available upon request.

40. Kreider, R.; Ellis, R. Number, Timing, and Duration of Marriages and Divorces; Census Bureau: Washington, DC, USA, 2009.

41. Akiba, D. Japanese Americans. In Asian Americans: Contemporary Trends and Issues, 2nd ed.; Min, P.G., Ed.; Sage: Thousand Oaks, CA, USA, 2006; pp. 148-177. ISBN 1-4129-0556-7.

42. Fujino, D.C. The Rates, Patterns and Reasons for Forming Heterosexual Interracial Dating Relationships among Asian Americans. J. Soc. Pers. Relationsh. 1997, 14, 809-828. [CrossRef]

43. Yang, P.Q.; Koshy, K. The "Becoming White Thesis" Revisited. J. Public Prof. Sociol. 2016, 8, 1-25. In the last two decades, there has been a discourse on the expansion of white category and the possibility for Asian Americans and Latinos to become white in the near future. Hence, "Asian Americans to become white" literally means what is stated. For more information on this discourse, the reader is referred to the works of Jonathan Warren and France Twine (1997), Herbert Gans (1999, 2012), George Yancey (2003), Edward Bonilla-Silva (2004), Min Zhou (2004), Philip Yang (2006), and Nadia Kim (2007), as cited in Yang and Koshy's (2016) article.

(C) 2018 by the authors. Licensee MDPI, Basel, Switzerland. This article is an open access article distributed under the terms and conditions of the Creative Commons Attribution (CC BY) license (http://creativecommons.org/licenses/by/4.0/). 